\title{
Mapping of sites in forest stands
}

\author{
SYLVIO PÉLLICO NETTO, FLAVIO R. STEFANELLO, \\ ALLAN L. PELISSARI and HASSAN C. DAVID \\ Departamento de Engenharia Florestal, Universidade Federal do Paraná, \\ Av. Pref. Lothário Meissner, 900, Jardim Botânico, Campus III, 80210-170 Curitiba, PR, Brasil \\ Manuscript received on December 9, 2013; accepted for publication on March 14, 2014
}

\begin{abstract}
Generally, the forest companies use the total one year planting area as a minimum stratum of the total population and, consequently, the forest inventory processing has been conducted by applying the stratified random sampling to it. This study was carried out in the National Forest of Tres Barras, Brazil, and it aimed to classify and map the sites of Pinus elliottii stands. A systematic sampling was structured into clusters and applied independently by compartments. The clusters, in maltese cross, were composed of four sampling subunits, using Prodan sampling method with a fixed number of six trees. By analysis of the methodology it was possible to confirm the hypothesis: a) the selective thinning cause expressive increase of volumetric variability within compartments; b) the variation of sites within the compartments causes volumetric expansion of variance and this grows proportionally to the quality of the sites; c) the stratification in sites results in minimum variance within them; d) the stratification in sites resulted in until to $91 \%$ reduction of variances within them.
\end{abstract}

Key words: Pinus elliottii, Prodan's sampling method, stratification by sites, spatial variation.

\section{INTRODUCTION}

The demand for forest products maintains close link with the increase of human population and, as the present expectations, the human population growth rate indicates trends of continuous advance. This fact signals that the forestry sector needs to increase investments in reforestations and improve the quality of products and forest services. With the support and development of new technologies it will become possible to benefit society directly, by answering the market demand and indirectly, by the decrease of exhaustion of natural forests.

The forests planted with conifers, today in adult state in Brazil, are derived from projects, in their majority from fiscal incentive of decades from 1960 to 1980, having its deployment focused more on quantity of reforested area and little in the quality of the production. In these circumstances, the basic criteria for conducting such plantations were often ignored, which is why it became relevant enhancement studies for its quantification.

Correspondence to: Sylvio Péllico Netto

E-mail: sylviopelliconetto@gmail.com 
In the literature there are some studies (Tonini et al. 2002, Raulier et al. 2003, Bravo-Oviedo et al. 2004, Palahi et al. 2004, Rivas et al. 2004, Aertsen et al. 2010, Vargas-Larreta et al. 2010, Kitikidou et al. 2011) that show, mainly for coniferous forests of the genus Pinus sp., different local qualities, which are indices relating to their potential productivity and obtained in a direct way. Despite the merit and importance of these studies, there are no records documented that such contributions have been complemented with work relating to mapping of indices of productivity, of fundamental importance as a final process of stratification, which would allow more accurate information and reliable to forest inventory and, consequently, to the forest management and the planning of production use.

Generally forestry companies adopt an inventory planning, in which only one or two plots are allocated in each compartment, or one or two plots every twenty five hectares. This spatial sample allocation is adopted due to the cost that data collection represents for the company. By doing so, without detailing the stratification up to units of site, the sampling estimates do not reach the required standards of precision. On the other hand, if the planning of sampling scheme is performed according to a previous study of the site qualities, this procedure may produce more reliable and more accurate results. In this context, the application of a systematic network of sampling units in the compartments will ensure that all possible productivity classes will be detected by the sampling procedure.

In addition, the companies use the total yearly planted area as a minimum stratum of the total population - MSP and consequently the forest inventory is conducted by applying strictly the stratified random sampling up to this level, with total abstention of sample evaluation within the compartments and without detail of stratification within this MSP.

In the light of the foregoing and aiming to contribute to technical-scientific knowledge on planted forests, particularly in those of the genus Pinus, this work was conducted to implement the mapping of site classes, which required prior knowledge of site limits at various points in the area selected for this particular experiment. With this purpose, it was appropriate to use a systematic sampling in two stages, with clusters in the first stage and Prodan's sampling points with the six nearest trees from a central point in the second stage. Also it was required the site index classification and conclusively the effective mapping of the sites, which aimed at detection of variability of production in those new strata of the MSP. The objective of this study was to detect the variability of production, quantified in $\mathrm{m}^{3}$ of wood with bark per hectare by compartments, in forest stands of Pinus elliottii Engelm. var. elliottii, to evaluate the appropriateness of stratification by site.

As hypothesis: 1) The application of selective thinning in compartments of Pinus elliottii var. elliottii causes significant increase of volumetric variability within them; 2) The variation of sites within compartments causes volumetric expansion of the variance and this grows proportionally to the quality of the sites; 3) The stratification of MSP in sites results in minimum variance within them; 4) It will occur expressive volumetric reduction of variance, when the stratification is performed by site units in the MSP.

\section{MATERIALS AND METHODS}

STUdy AREA AND DATA COLLECTION

The data were collected in the National Forest of Três Barras, in the municipality of Três Barras, State of Santa Catarina, Brazil. The climate of the region is of type $\mathrm{Cfb}$, according description of Köppen, with rains well distributed during the year and the average temperature of the coldest month below $18^{\circ} \mathrm{C}$. The relief is 
slightly undulated and the soils are of type silty-clayey to clayey, with good water retention capacity and, in general, overly acidic. The vegetation cover is composed of fragments of Mixed Ombrophilous Forest and forest stands of species of the genus Pinus.

Stands of Pinus elliottii var. elliottii were selected for data collection, based on the criterion of larger coverage area of this species inside the limits of that conservation unit, encompassing seven compartments, with a total area of approximately 940 ha and that aimed at identifying variation of existing productivity in the sites, using a systematic grid of clusters composed of four subunits sampled with the Prodan's sampling points.

The permanent plots or units of fixed area (UFA) were allocated using the simple random sampling, whose selection obeyed the criterion of randomization of points of the systematic sample network. This meant that two random selected plots of fixed area always were located at two corresponding sampling units of the systematic grid. Therefore, two ( $n$ ) out of twenty five points $(C)$ of the grid were used for the random sampling, as is commonly made by the companies. For each compartment it was defined a square grid of twenty five clusters, whose structure was organized in accordance with Cochran (1977), Hush et al. (1972) and Sukhatme and Sukhatme (1970).

The systematic sampling was applied independently in each compartment. Their sampling units were clusters (C) with M subunits (SU). Thus, the population sampled has C clusters, each containing M subunits, in which $\mathrm{i}=1,2 \ldots \mathrm{C}$ and $\mathrm{j}=1,2 \ldots \mathrm{M}$ respectively, with the restriction that the number of clusters would be equal in each of the compartments that comprise the forest population to allow a fair comparison of its production. The variable volume $\left(\mathrm{m}^{3}\right)$, object of analysis, represented by $Y_{i j}$, was the value observed in $\mathrm{j}^{\text {th }}$ cluster, inside the $\mathrm{i}^{\text {th }}$ subunit - SU.

The density $\left(n h a^{-1}\right)$, of the Prodan's sampling point was obtained by taking 5.5 trees observed in a circular variable area until the $6^{\text {th }}$ nearest tree of sample point, computed as half $(0.5)$ tree, by living and at the same time be the limit of the marginal circle that includes it, as defined by Prodan (1968), Pelz (1983) and Péllico Netto and Brena (1997).

The methodology to calculate the density per hectare, developed by Péllico Netto (1994), was adopted in this study with the purpose of defining the criterion of more precise proportion of participation of the $6^{\text {th }}$ tree $\left(\mathrm{K}_{i}\right)$ in sample subunit (1).

$$
K_{i}=\operatorname{sen}^{-1}\left(\sqrt{R_{6}^{2}-r_{6}^{2}}\right)\left(180^{\circ} R_{6}\right)^{-1}
$$

In which: $R_{6}=$ marginal radius of the sixth tree; and $r_{6}=$ radius of the cross sectional area of the sixth tree. The density per subunit $\left(D_{i j}\right)$ is obtained by (2)

$$
D_{i j}=10^{4}\left(5+K_{i j}\right)\left(\pi R_{i j}^{2}\right)^{-1}
$$

The density per cluster $\left(D_{i}\right)$ is obtained by (3)

$$
D_{i}=\left(\sum_{j-1}^{m} D_{i j}\right) 4^{-1}
$$

\section{Evaluation of productive capacity and mapping of site unites}

Anamorphic curves of site index were constructed by the method of a guide curve, according to Campos and Leite (2006) and Scolforo (2006), adopting the criterion of dominant height $\left(H_{d o m}\right)$ from Assmann, corresponding to the arithmetic mean of the heights from the 100 larger trees in diameter per hectare, as a 
function of age (I), and fitted to the Prodan's model (1965), during the elaboration of the management plan for that conservation unit (Project Flonas Fupef/Ibama 1989) as presented in (4).

$$
H_{\text {dom }}=I^{2}\left(\beta_{0}+\beta_{1} I+\beta_{2} I^{2}\right)^{-1}=I^{2}\left(8.8865-0.5303+0.0452 I^{2}\right)^{-1}
$$

To describe and model the spatial patterns of site index it was used the geostatistic analysis with the adjustment of a spherical semivariograma model (Vieira 2000, Andriotti 2003), as presented in (5), and aid of the computer program Geoest (Vieira et al. 2002), with coefficient of determination $\left(\mathrm{R}^{2}\right)$ of 0.996 and weighted sum of squared deviations (WSSD) equal to 0.0079 .

$$
y(h)=C_{0}+C\left[1-e^{\left(-h^{2} / A^{2}\right)}\right]=1.6425+1.1211\left[1-e^{\left(-h^{2} / 1,941^{2}\right)}\right]
$$

where:

$\mathrm{y}(\mathrm{h})=$ semivariance, $\mathrm{h}=$ distance, $\mathrm{C}_{0}=$ nugget effect, $\mathrm{C}=$ sill, and $\mathrm{A}=$ range.

The interpolation and the spatialization were performed by ordinary punctual kriging, that considers the spatial dependence and prepare of thematic maps without bias and with minimum variance (Corá and Beraldo 2006), being drawn up with the program Surfer 9.0, demonstration version (Golden Software 2002), using the limits of dominant heights for site classes at 25 years as reference age.

\section{ESTIMATION OF VOLUMETRIC PRODUCTION}

The calculation of volumetric production was performed with the application of the Schumacher-Hall volumetric equation fitted for the species Pinus elliottii var. elliottii in the National Forest of Três Barras, according to the Final Report of the Project Flonas Fupef/Ibama (1989), as presented in (6).

$$
\ln v=\beta_{0}+\beta_{1} \ln d+\beta_{2} \ln h=-9.8618+1.8312 \ln d+1.0967 \ln h
$$

After the compartment maps were at our disposal, with a network of points properly configured, it was identified the line, the cluster central points (C) and the four points of the subunits (SU). It was identified the six closest trees to the central point of the four subunits, measured their diameters and heights and the respective distance from this center up to the $6^{\text {th }}$ tree of each (SU). The volume of the (SU) was determined using the volume equation for each tree sampled and performed the summation of individual volumes, except the $6^{\text {th }}$ tree to which it was applied the discount, as is referred in (1).

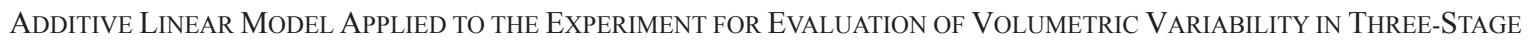

HiERARCHICAL STRUCTURE OF SAMPLE

The organization of the Additive Linear Model for application of analysis of variance to a three stages structure, which characterizes a nested hierarchical model, i.e., the second stage is subordinate to the first stage and the third stage is subordinate to the second stage, is described below.

The compartments are the primary units (PU), such that $i=1,2,3 \ldots L$, in which $L$ is the number of all compartments that compose the population to be assessed, i.e., there is no sampling in the first stage.

$\mathrm{Be}$, subsequently, considered the clusters (C) within the (PU), such that $j=1,2,3 \ldots C$, in which $C$ is pre-fixed, i.e., $C=25$ clusters by (PU), not configuring sampling at this stage.

It is considered, by order, the subunits of the clusters (SU), such that $k=1,2,3 \ldots M$, in which $M$ is pre-fixed, i.e. $M=4$ subunits in each cluster, also not configuring sampling in this last stage, becoming consequently the experimental error. 
As the additive linear model is hierarchical, then it is designed as presented in (7).

$$
X_{i j k}=\mu+a_{i}+\beta_{j(i)}+\varepsilon_{k(j i)}
$$

From the final composition of the components of variation of the linear model proposed above, the analysis of variance is presented in Table I.

TABLE I

Structure of the analysis of variance to be applied to the experiment.

\begin{tabular}{l|l|l|l}
\hline Source of Variation & Mathematical Expectation & Assumptions & F Test \\
\hline Compartments (L) & $S_{\varepsilon}^{2}+C M \sum_{k=1}^{M} \alpha_{i}^{2}(M-1)^{-1}$ & $H_{0}: \alpha_{i}^{2}=0$ & $F_{1}=M Q_{\alpha} / M Q_{\varepsilon}$ \\
\hline Clusters (C) within (L) & $S_{\varepsilon}^{2}+M \sum_{j=1}^{C} \sum_{k=1}^{M} \beta_{j(i)}^{2}[C(M-1)]^{-1}$ & $H_{0}: \beta_{j(i)}^{2}=0$ & $F_{2}=M Q_{\beta} / M Q_{\varepsilon}$ \\
\hline Subunits (M) within (C) & $S_{\varepsilon}^{2}$ \\
\hline Total & $S_{x}^{2}=C M \alpha_{i}^{2}(M-1)^{-1}+M \sum_{j=1}^{C} \sum_{k=1}^{M} \beta_{j(i)}^{2}[C(M-1)]^{-1}+S_{\varepsilon}^{2}$ \\
\hline
\end{tabular}

It is worth to clarify that the parameter variance can only be obtained as it is presented in Table I, if the components of variance between primary units and between the clusters exist, i.e., if the null hypotheses are both rejected. In the case of acceptance of the null hypothesis in one or both cases, the variance components are obtained by weighted averages using the appropriate combinations of the mathematical expectations.

By the application of analysis of variance to the experimental data we have:

Average of all the subunits in population

$$
\bar{X}=\sum_{i=1}^{L} \sum_{j=1}^{C} \sum_{k=1}^{M} X_{i j k}(N C M)^{-1}
$$

Average per subunit in each compartment (PU)

$$
\bar{X}_{i}=\sum_{j=1}^{C} \sum_{k=1}^{M} X_{i j k}(C M)^{-1}
$$

Average per subunit for each one of the clusters within each primary unit (PU)

$$
\bar{X}_{i j}=\sum_{k=1}^{M} X_{i j k}(M)^{-1}
$$

General Variance per subunit

$$
S_{x}^{2}=\sum_{i=1}^{L} \sum_{j=1}^{C} \sum_{k=1}^{M}\left(X_{i j k}-\bar{X}\right)^{2}(N C M-1)^{-1}
$$

By ANOVA, the total variance, under the condition of rejection of null hypotheses, is obtained by:

$$
S_{x}^{2}=C M \sum_{k=1}^{M} \alpha_{i}^{2}(M-1)^{-1}+M \sum_{j=1}^{C} \sum_{k=1}^{M} \beta_{j(i)}^{2}[C(M-1)]^{-1}+S_{\varepsilon}^{2}
$$


In that:

$S_{\varepsilon}^{2}$ Is the average variance between subunits within the clusters (C) considering all the primary units (PU)

$C M \sum_{k=1}^{M} \alpha_{i}^{2}(M-1)^{-1}$ is the variance between the primary units (PU)

$M \sum_{j=1}^{C} \sum_{k=1}^{M} \beta_{j(i)}^{2}[C(M-1)]^{-1}$ is the variance between the means of clusters (C) within the primary units (PU)

Obtaining the Mean Squares in ANOVA

Mean Square between the primary units (PU)

$$
M Q_{e(P U)}=C M \sum_{i=1}^{L}\left(\bar{X}_{i}-\bar{x}\right)^{2}(N-1)^{-1}
$$

Mean Square between the clusters within the primary units (PU)

$$
M Q_{e(C G)}=M \sum_{i=1}^{L} \sum_{j=1}^{C}\left(\bar{X}_{i j}-\bar{X}_{i}\right)[N(C-1)]^{-1}
$$

Mean Square between the subunits of clusters within the primary units (PU)

$$
M Q_{e(S U)}=\sum_{i=1}^{L} \sum_{j=1}^{C} \sum_{k=1}^{M}\left(X_{i j k}-\bar{X}_{i j}\right)^{2}[N C(M-1)]^{-1}
$$

Variance between the primary units:

$$
C M \sum_{k=1}^{M} \alpha_{i}^{2}(M-1)^{-1}=\frac{M Q_{e(U P)}-M Q_{e(S U)}}{C M}
$$

Variance between clusters, when the null hypothesis is rejected:

$$
M \sum_{j=1}^{C} \sum_{k=1}^{M} \beta_{j(i)}^{2}[C(M-1)]^{-1}=\frac{M Q_{e(C G)}-M Q_{e(S U)}}{M}
$$

And

$$
S_{\varepsilon}^{2}=M Q_{e(S U)}
$$

Therefore the total variance can be calculated as follows, in the condition in which both null hypotheses are rejected:

$$
s_{x}^{2}=\frac{M Q_{e(P U)}+C\left(M Q_{e(C G)}\right)+M Q_{e(S U)}[C(M-1)-1]}{M C}
$$

The variance of the mean can be obtained as follows:

$$
s_{\bar{x}}^{2}=\left(\frac{L-L}{L}\right) \frac{C M \sum_{k=1}^{M} \alpha_{i}^{2}(M-1)^{-1}}{L}+\left(\frac{C-C}{C}\right) \frac{M \sum_{j=1}^{C} \sum_{k=1}^{M} \beta_{j(i)}^{2}[C(M-1)]^{-1}}{L C}+\frac{S_{\varepsilon}^{2}}{L C M}
$$

As observed, the variance of the mean is reduced only to the value of the variance between the subunits, since the sample fractions do not occurr between compartments and between clusters. It is obtained as follows:

$$
s \frac{2}{\bar{x}}=\frac{S_{\varepsilon}^{2}}{L C M}
$$


The standard deviation can be obtained as follows:

$$
s_{\bar{x}}=\sqrt{\frac{S_{\varepsilon}^{2}}{L C M}}
$$

The coefficient of variation can be obtained as follows:

$$
c v=\frac{s_{x}}{\bar{x}} 100
$$

The standard error percentage can be obtained as follows:

$$
s_{\bar{x}} \%=\frac{s_{\bar{x}}}{\bar{x}} 100
$$

The intracluster correlation coefficient can be obtained as follows:

$$
\rho=\frac{M \sum_{j=1}^{C} \sum_{k=1}^{M} \beta_{j(i)}^{2}[C(M-1)]^{-1}}{M \sum_{j=1}^{C} \sum_{k=1}^{M} \beta_{j(i)}^{2}[C(M-1)]^{-1}+S_{\varepsilon}^{2}}
$$

\section{RESULTS AND DISCUSSION}

\section{Statistical Tests}

The population, composed of seven compartments, was stratified according to age, i.e., the compartments 64 , 66 and 67 formed the stratum I ( 25 years old, in which it was carried out selective thinning) and compartments 76A, 76B, 76C and 76D formed the stratum II (20 years old, before the last thinning). The statistical analyzes is presented in Table II, for of stratification components by age and comparison by " $t$ " test.

TABLE II

Statistical analyzes applied to fixed area plots measured in seven compartments allocated into two strata separated by age.

\begin{tabular}{ccccccc}
\hline Age $($ year $)$ & $n$ & Mean $\left(\mathrm{m}^{3} \mathrm{ha}^{-1}\right)$ & Variance $\left(\mathrm{m}^{3} \mathrm{ha}^{-1}\right)^{2}$ & Standard Deviation $\left(\mathrm{m}^{3} \mathrm{ha}^{-1}\right)$ & Hartley test & " $t^{\prime \prime}$ test \\
\hline $25(\mathrm{I})$ & 6 & 458.6 & $30,301.2$ & 174.1 & $7.20 *$ & \multirow{2}{*}{$0.155 \mathrm{~ns}$} \\
$20(\mathrm{II})$ & 8 & 470.2 & $4,205.6$ & 64.9 & & \\
\hline
\end{tabular}

Where: $n=$ number of sample units of fixed area; * = significance level of $5 \%$ of probability; and ns $=$ not significant.

As observed in Table II, there was significance at 95\% probability between the variances by application of the Hartley' s test, consequently the tabulated value of ' $t$ ' should be corrected according Cochran and Cox (1957), i.e.:

$$
t^{\prime}=\frac{w_{1} t_{1}=w_{2} t_{2}}{w_{1}=w_{2}}=\frac{(5050.20)(2.571)+(525.70)(2.365)}{5050.20+525.70}=\frac{14227.3447}{5575.90}=2.552
$$

where

$w_{1}=s_{1}^{2} n_{1}^{-1} ; w_{2}=s_{2}^{2} n_{2}^{-1} ; t_{1}$ and $t_{2}$ are respectively the table values of " $t$ " for $n_{1}-1$ e $n_{2}-1$ degrees of freedom.

Still referring to Table II, the application of selective thinning has changed the structure of the population with an increase of 7.2 times the variance on volume in the compartments for the stratum I ( 25 years old), which proves the first hypothesis presented in this work. 
The reduction of the volumetric stock in stratum I, due to thinning, made it possible an approximation of the volumes in the two strata, which are common in these circumstances, but such an expressive increase of variance explains the reduction of precision when the results of the continuous forest inventories are reported for this species.

For the statistical analysis of the systematic sampling, the population was stratified using the compartments as administrative strata. Due to the high sampling intensity applied within the compartments it has become important also to analyze the behavior of the variances within them, mainly to assess the influence of thinning application. Still, this analysis was conducted in two stages: the first was individually applied within each compartment, with a sample of clusters taken in each compartment, in which the clusters will detect the spatial variability of volume within them (Tables III and IV) and, in addition, the variability between them (Table V).

As seen in Table III, the behavior of the total variances $\left(S_{T}^{2}\right)$ and the respective estimators of the intracluster correlation coefficient $(\hat{\rho})$ shows the influence of the sites in results of volumetric estimators by cluster, whose interpretative synthesis is presented in Table IV. These results prove the second hypothesis.

TABLE III

Summary of the intracluster correlation coefficients applied to the systematic sampling of clusters (C) in each compartment (PU).

\begin{tabular}{cccccccc}
\hline & \multicolumn{7}{c}{ Compartments } \\
\cline { 2 - 8 } & $\mathbf{6 4}$ & $\mathbf{6 6}$ & $\mathbf{6 7}$ & $\mathbf{7 6 A}$ & $\mathbf{7 6 B}$ & $\mathbf{7 6 C}$ & $\mathbf{7 6 D}$ \\
\hline$\overline{\bar{y}}$ & 487.384 & 246.044 & 317.908 & 429.450 & 430.175 & 411.196 & 380.560 \\
$c v \%$ & 42.75 & 53.16 & 56.38 & 41.77 & 57.85 & 55.72 & 37.56 \\
$s_{d}^{2}$ & $35,292.4$ & $8,913.80$ & $26,504.40$ & $19,782.50$ & $36,119.00$ & $33,282.20$ & $19,484.50$ \\
$S_{e}^{2}$ & $8,128.4$ & $8,193.70$ & $5,623.10$ & $12,388.90$ & $25,813.50$ & $19,210.80$ & 946.80 \\
$s_{T}^{2}$ & $43,420.8$ & $17,107.40$ & $32,127.40$ & $32,171.40$ & $61,932.50$ & $52,493.10$ & $20,431.30$ \\
$\hat{\rho}$ & 0.19 & 0.48 & 0.18 & 0.39 & 0.42 & 0.37 & 0.05 \\
$n$ & 8 & 6 & 16 & 20 & 14 & 16 & 5 \\
$M$ & 4 & 4 & 4 & 4 & 4 & 4 & 4 \\
\hline
\end{tabular}

Where: $\overline{\bar{y}}=$ average; $c v \%=$ coefficient of variation; $s_{d}^{2}=$ variance within clusters; $s_{e}^{2}=$ variance between clusters; $s_{T}^{2}=$ total variance of clusters; $\hat{\rho}=$ estimate of the intracluster correlation coefficient; $n=$ number of clusters sampled; and $M=$ number of Prodan's sampling points per cluster.

TABLE IV

Summary of the results of Table III for the compartments sampled.

\begin{tabular}{cccc}
\hline $\begin{array}{c}\text { Intracluster } \\
\text { correlation coefficient }\end{array}$ & Situation & Compartments & Evaluation \\
\hline $0.00-0.10$ & $\begin{array}{c}\text { Homogeneous within } \\
\text { the compartments } \\
\text { Semi-homogeneous within } \\
\text { the compartments } \\
\text { Heterogeneous within } \\
\text { the compartments }\end{array}$ & 67 and 64 & A single site \\
$>0.10-0.20$ & $\begin{array}{c}\text { Two sites, but with high } \\
\text { preponderance of a single site }\end{array}$ \\
\hline
\end{tabular}


As presented in the methodology, the stratification in three-stage hierarchical design allows you to evaluate in a global manner throughout the experimental structure. That way, it can test the degree of volumetric homogeneity among compartments and between the clusters within the compartments, whose result is presented in Table $\mathrm{V}$.

TABLE V

Analysis of variance of the systematic sampling stratified by compartments.

\begin{tabular}{ccccccc}
\hline Sources of Variation & GL & SQ & MQ & F & F 5\% & F 1\% \\
\hline Between compartments & 6 & $3,514,024.75$ & $585,670.79$ & $165.50 * *$ & 2.12 & 2.84 \\
Between clusters within compartments & 168 & $1,547,971.31$ & $9,214.11$ & $2.60 * *$ & 1.22 & 1.33 \\
Between subunits within clusters & 525 & $1,857,828.10$ & $3,538.72$ & & & \\
\hline Total & 699 & $6,919,824.16$ & & & \\
\hline
\end{tabular}

Where: $* *=$ significant at $1 \%$ of probability level.

As observed in Table V, it has occurred significances at 99\% probability level between compartments and also between the clusters within the compartments. These results clearly show the need to stratify populations by site. As the compartments are administrative units within the MSP, only partially reduces the total variance, remaining the variation due to the sites. In the same way, the high significance observed among the clusters within the compartments portrays the heterogeneity due to the sites.

TABLE VI

Statistics of the sampled population.

\begin{tabular}{ccccc}
\hline Estimators & Between compartments & Between clusters & Within clusters & Total \\
\hline Variances (all stages) & $5,821.32$ & $1,418.85$ & $3,538.72$ & $10,778.89$ \\
Variances (only & - & $1,418.85$ & $3,538.72$ & $4,957.57$ \\
clusters) & - & - & - & $28.87 \%$ \\
$c v \%$ & - & - & - & $0.26 \%$ \\
$S_{\bar{x}} \%$ & - & - & - & 0.29 \\
$\hat{\rho}$ & & &
\end{tabular}

Where: $c v \%=$ coefficient of variation; $S_{\bar{x}} \%=$ standard error percentage; and $\hat{\rho}=$ estimate of the intracluster correlation coefficient.

TABLE VII

Analysis of variance for site classes with systematic sampling.

\begin{tabular}{|c|c|c|c|c|c|c|c|c|}
\hline \multicolumn{2}{|c|}{ Strata } & \multirow{2}{*}{$N$} & \multirow{2}{*}{$s_{e}^{2}$} & \multirow{2}{*}{$s_{d}^{2}$} & \multirow{2}{*}{$s_{T}^{2}$} & \multirow{2}{*}{$\begin{array}{c}S_{T}^{2} \\
\text { Media }\end{array}$} & \multirow{2}{*}{$F$} & \multirow{2}{*}{$\hat{\rho}$} \\
\hline Age (year) & Site classes & & & & & & & \\
\hline \multirow{2}{*}{25} & III & 31 & 719.8 & $1,064.0$ & $1,783.7$ & \multirow{2}{*}{$2,498.0$} & $3.71 *$ & 0.404 \\
\hline & IV & 43 & $1,482.2$ & $1,730.0$ & $3,212.3$ & & $4.43 *$ & 0.461 \\
\hline \multirow{2}{*}{20} & II & 90 & 378.5 & 451.6 & 830.1 & \multirow{2}{*}{787.1} & $4.35 *$ & 0.456 \\
\hline & III & 11 & 331.8 & 412.4 & 744.1 & & $4.22 *$ & 0.446 \\
\hline
\end{tabular}

Where: $s_{e}^{2}=$ variance between clusters; $s_{d}^{2}=$ variance within clusters; $s_{T}^{2}=$ total variance of clusters; $F=$ variance ratios to test hypothesis of means; $\hat{\rho}=$ estimate of the intracluster correlation coefficient; $N=$ number of clusters; and * significance at $5 \%$ probability.

For better understanding of these results of the ANOVA, a synthesis of the statistics is presented in Table VI. Note that the variance between the compartments represents more than $50 \%$ of total variance, indicating once again that there is a need to delimit sites as last step of stratification within the MSP. The coefficient of variation of the order of $30 \%$ is due to the application of thinning in the stands with 25 years, 
which caused approximation of the volumetric means at both ages (25 and 20 years). The precision of this sampling design, of the order of $0.26 \%$, occurred by the high intensity of clusters sampled in each compartment ( 25 units) and also because the ANOVA model, composed of fixed effects in the first two levels of stratification, enables the calculation of standard error in percentage only as function of the variance within clusters. The intracluster correlation coefficient $(0.29)$ shows once more the heterogeneity among the clusters, i.e., the variability of the clusters' means within the compartments, of the order of $30 \%$ of their total variability, corresponds to the average value of the intracluster correlation coefficients calculated independently within each compartment, as shown in Table III.

\section{MAPPING OF Classes of Site}

With the objective of checking if the stratification in sites in the population results statistical significance, the mapping of site index classes was performed at the level of compartments, that is, the population refers to the sum of them (Figure 1).

The analysis of variance was conducted using only the clusters within the sites and also separated by age, exactly to keep one year of planting as the basic unit for stratification. This adopted procedure for the analysis of variance was described by Ostle and Mensing (1975) (Table VII).

As seen in Table VII, we proved what was formulated in the third hypothesis, because there was significant reduction of the variance on volume, when the clusters were processed only within each unit of site, the new stratification procedure within the EMP. The mean variance in the age of 25 years is kept higher than that at the age of 20 years, due to the application of selective thinning in the older stands.

The results of the ANOVA showed that remains significance at $95 \%$ probability among the clusters within the strata, expressed by the uniformity of the intracluster correlation coefficient in all of them, showing that their total variances comprise approximately $45 \%$ between clusters and $55 \%$ within them. These results are attributed to the occurrence of uneven density within sites, whether by effect of thinning in stands of 25 years, or by mortality in stands of 20 years.

\section{SYSTEMATIC VERSUS RANDOM SAMPLING}

The comparison of the results obtained by applying the two sampling procedures is presented in Table VIII.

TABLE VIII

Comparison of average and total production by compartments with random sampling (plots) and systematic sampling (clusters).

\begin{tabular}{ccccc}
\hline \multirow{2}{*}{ Compartments } & \multicolumn{2}{c}{ Random Sampling (plots) } & \multicolumn{2}{c}{ Systematic Sampling (clusters) } \\
\cline { 2 - 5 } & Volume $\left(\mathrm{m}^{3} \mathrm{ha}^{-1}\right)$ & Total Production $\left(\mathrm{m}^{3}\right)$ & Volume $\left(\mathrm{m}^{3} \mathrm{ha}^{-1}\right)$ & Total Production $\left(\mathrm{m}^{3}\right)$ \\
\hline 64 & 638.123 & $14,893.800$ & 487.384 & $1,375.530$ \\
66 & 295.565 & $8,000.940$ & 246.044 & $6,660.320$ \\
76 & 442.104 & $22,503.070$ & 317.908 & $16,183.170$ \\
$76 \mathrm{~B}$ & 493.513 & $27,819.340$ & 429.450 & $24,101.540$ \\
$76 \mathrm{C}$ & 472.101 & $13,596.500$ & 430.175 & $12,353.280$ \\
$76 \mathrm{D}$ & 458.068 & $25,935.780$ & 411.196 & $23,281.970$ \\
Mean*/Total $_{\mathrm{IC}}$ & 456.957 & $7,146.800$ & 380.560 & $5,952.560$ \\
\hline
\end{tabular}

Where: * Weighted mean; ** IC with 5\% probability. 
TABLE IX

Comparison of the variances of the variable volume obtained without and with stratification by sites.

\begin{tabular}{cccc}
\hline \multirow{2}{*}{ Age (year) } & \multicolumn{3}{c}{ Variance $\left(\mathrm{m}^{3} \mathrm{ha}^{-1}\right)^{2}$} \\
\cline { 2 - 4 } & Without stratification & With stratification by sites & Variance reduction $(\%)$ \\
\hline 25 & $30,301.18$ & $2,498.00$ & $91.76 \%$ \\
20 & $4,205.64$ & 787.10 & $81.28 \%$ \\
\hline
\end{tabular}

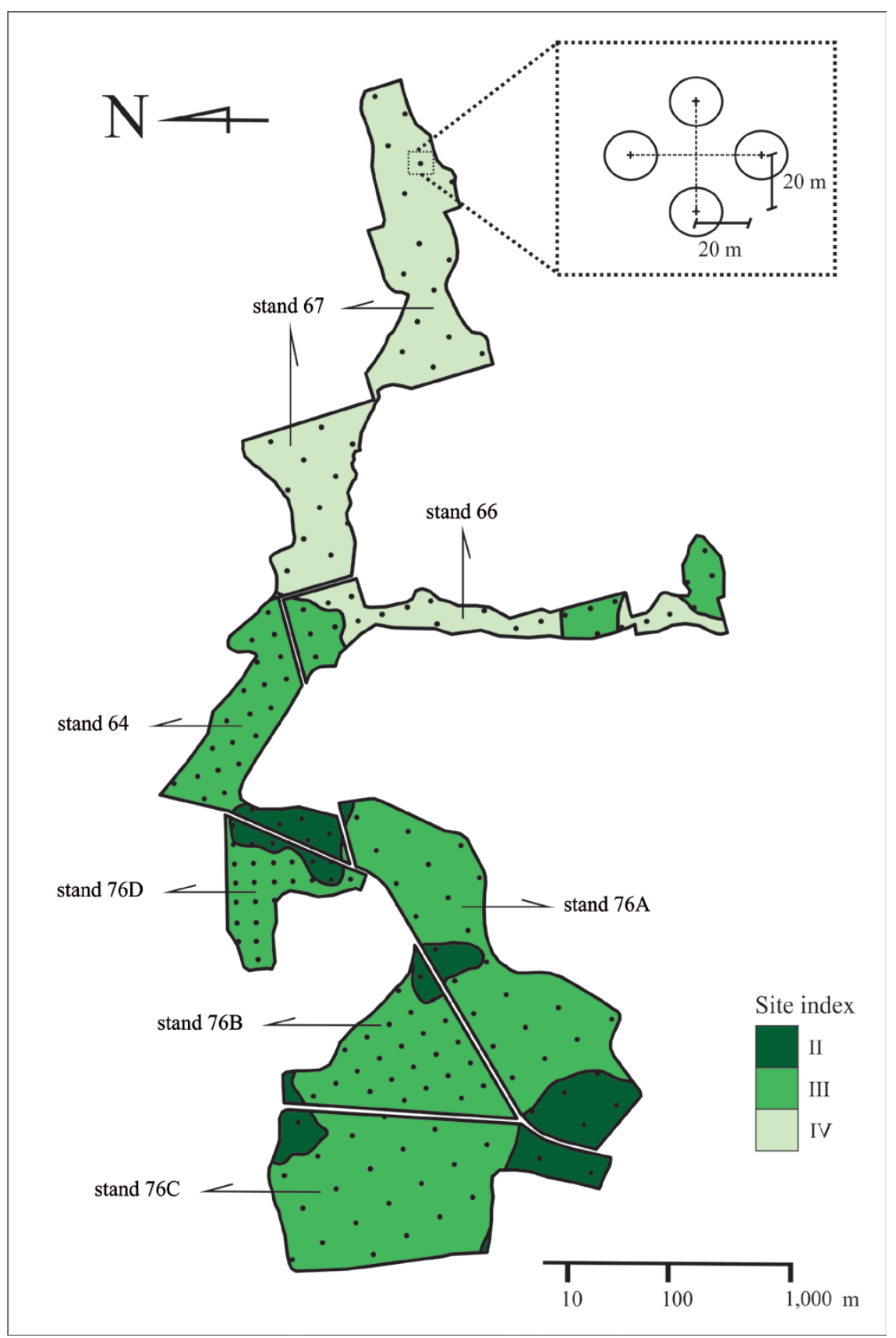

Figure 1 - Geographical location of the cluster units in a systematic pattern and identification of the number and boundaries of the sites within the compartments. 
The large increase in precision obtained in the application of clusters was due to greater coverage in the detection of internal variability in the compartments and the high sampling intensity applied (25 clusters with four subunits each, totaling 100 subunits in each compartment and 700 in all compartments), compared with 14 units of plots used in the random sampling (two plots per compartment).

Conclusively, the comparison of variances obtained by the two procedures used in this study, the traditional one used by companies and the stratification by sites, is synthesized in Table IX.

As seen in Table IX, the reductions of variances by application of stratification by sites has reached $91.76 \%$, occurred in stands with 25 years and $81.28 \%$ for the stands of 20 years. Such results are very expressive and prove the fourth hypothesis formulated in this work.

To improve the structure of continuous forest inventories in the companies and significantly increase of the precision of sampling estimators, it is strongly recommended the stratification by production sites in the MSP.

\section{RESUMO}

Geralmente as empresas florestais usam a área total de um ano de plantio como estrato mínimo do total da população e, consequentemente, o processamento do inventário florestal tem sido realizado pela aplicação da amostragem aleatória estratificada. Este estudo foi realizado na Floresta Nacional de Três Barras, Brasil, e teve como objetivo classificar e mapear os locais onde Pinus elliottii se destaca. A amostragem sistemática foi estruturada em grupos e aplicada de forma independente por compartimentos. Os conglomerados em cruz maltesa, foram compostos por quatro subunidades de amostragem, utilizando o método de amostragem Prodan com um número fixo de seis árvores. Pela análise da metodologia, foi possível confirmar as hipóteses: a) o afinamento seletivo causa expressivo aumento de variabilidade volumétrica dentro dos compartimentos; b) a variação de locais no interior dos compartimentos provoca a expansão volumétrica de variância e esta cresce proporcionalmente à qualidade dos sítios; c) a estratificação em locais resulta em menor variância dentro deles; d) a estratificação em locais resultou em redução de até $91 \%$ das variâncias dentro deles.

Palavras-chave: Pinus elliottii, amostragem de Prodan, estratificação por sítios, variabilidade espacial.

\section{REFERENCES}

Aertsen W, Kint V, VAn Orshoven J, ÖZKan K And Muys B. 2010. Comparison and ranking of different modeling techniques for prediction of site index in Mediterranean mountain forests. Ecol Model 221: 1119-1130.

ANDRIOTTI JLS. 2003. Fundamentos de estatística e geoestatística, São Leopoldo, 165 p.

Bravo-Oviedo A, Rio MD And Montero G. 2004. Site index curves and growth model for Mediterranean maritime pine (Pinus pinaster Ait.) in Spain. For Ecol Manage 201: 187-197.

CAMPOS JCC AND LeITE HG. 2006. Mensuração florestal, $2^{\mathrm{a}}$ ed., Viçosa, 470 p.

COCHRAN WG. 1977. Sampling techniques. $3^{\text {rd }}$ ed., New York, J Wiley \& Sons, Inc., 428 p.

Cochran WG AND Cox GM. 1957. Experimental Design, $2^{\text {nd }}$ ed., New York, J Wiley \& Sons, Inc., 611 p.

CORÁ JE AND BERALDO JMG. 2006. Spatial variability of soil properties before and after lime and phosphorus fertilizer application at variable rates in sugarcane. Eng Agric 26(2): 374-387.

GoldEN SOFTwARE. 2002. Surfer: user's guide, Colorado, Golden Software, 664 p.

Hush B, Miller CI ANd Beers TW. 1972. Forest mensuration, $2^{\text {nd }}$ ed., New York, The Ronald Press Company, 410 p.

Kitikidou K, Bountis D And Milios E. 2011. Site index models for calabrian pine (Pinus brutia Ten.) in Thasos Island, Greece. Cienc Flor 21(1): 125-131.

Ostle B And Mensing RW. 1975. Statistics in research. $3^{\text {rd }}$ ed., Iowa, The Iowa State University Press, 596 p.

Palahi M, Tome M, Pukkalac T, Trasobares A And Monterod G. 2004. Site index model for Pinus sylvestris in north-east Spain. For Ecol Manage 187: 35-47.

PÉLLICO NETTO S. 1994. Correction factor for marginal trees in sampling methods with probabilistic selection proportional to a size. Cerne 1(1): 17-27.

PÉLlico NeTTO S AND BRENA DA. 1997. Inventário Florestal, Curitiba, Editorado pelos autores, 316 p. 
PELZ DR. 1983. Sixth-tree sampling in forest inventories. Floresta 14(1): 54-58.

Prodan M. 1965. Holzmesslehre, Franfurt, J.D. Sauerländer's Verlag, 644 p.

Prodan M. 1968. Punktstichprobe für die forsteirichtung. Forst U Holzwirt 23(11): 225-226.

ProjeCt Flona FUPEF/IBAMA. 1989. Inventário de Florestas Plantadas da Floresta Nacional de Três Barras/SC, Curitiba.

RAULIER F, LAMBert M, POTHIER D AND UNG C. 2003. Impact of dominant tree dynamics on site index curves. For Ecol Manage 184: 65-78.

Rivas JJC, GonZÁLEZ JGA, GonZÁLEZ ADR AND GADOw K VON. 2004. Compatible height and site index models for five pine species in El Salto, Durango (Mexico). For Ecol Manage 201: 145-160.

SCOLFORO JRS. 2006. Biometria florestal: modelos de crescimento e produção florestal. Lavras, 393 p.

SUKHATME PV AND SUKHATME DL. 1970. Sampling theory of surveys with applications. $2^{\text {nd }}$ ed., Ames, Iowa, Iowa State University Press, $452 \mathrm{p}$.

Tonini H, Finger CAG, SchneIder PR And SpAThelf P. 2002. Graphical comparison among site index curves for Pinus elliottii and Pinus taeda, built at south Brazil. Cienc Flor 12(1): 143-152.

Vargas-Larreta B, Álvarez-González JG, Corral-Rivas JJ And Aguirre-CALderón ÓA. 2010. Development of dynamic site index curves for Pinus cooperi blanco. Rev Fitotec Mex 33(4): 343-351.

VIEIRA SR. 2000. Geostatistics in soil spatial variability studies. In: NOVAIS RF, ALVAREZ VVH AND SCHAEFER CEGR (Eds), Topics in soil science, Brazilian Society for Soil Science, Viçosa, p. 1-54.

VIEIRA SR, MiLlETE JA, TOPp GC AND REYNOLDS WD. 2002. Handbook for geostatistical analysis of variability in soil and meteorological parameters. In: ALVAREZ VVH, SCHAEFER CEGR, BARROS NF, MELLO JWV AND COSTA LM (Eds), Topics in soil science, Brazilian Society for Soil Science, Viçosa, p. 1-45. 
